\title{
POLISH ADAPTATION OF THE COPENHAGEN PSYCHOSOCIAL QUESTIONNAIRE II (COPSOQ II) IN POLISH PRISON SERVICE STAFF - A TOOL FOR PSYCHOSOCIAL RISK ASSESSMENT AT THE WORKPLACE
}

Katarzyna ORLAK¹, Dominik GOŁUCH ${ }^{2}$, Mikołaj STOLARSKI ${ }^{1,2}$

1 Zoom in on Posts - Association for Occupational Health Prevention, Warsaw, Poland

2 Institute of Psychology, Cardinal Stefan Wyszyński University in Warsaw, Warsaw, Poland

Source of support: Zoom in on Posts - Association on for Occupatioonal Health Prevention (Stowarzyszenie ZDROWA PRACA) and Autohors' own sources

Author's address: D. Gołuch, Institute of Psychology, Cardinal Stefan Wyszyński University in Warsaw, Wóycickiego 1/3 Street; 01-938 Warsaw, e-mail: d.goluch@uksw.edu.pl

Introduction: The Copenhagen Psychosocial Questionnaire (COPSOQ) is identified to be appropriate to assess psychosocial hazards at work and is recommended in WHO publications. However, the tool was never fully adopted in Poland. The purpose of this paper is to present the psychometric characteristics of COPSOQ II in Polish.

Material and A validation study of the long (128-item) COPSOQ II was conducted on a stratified sample Methods: of the Polish Prison Service staff $(\mathrm{N}=380)$. Reliability was tested with Cronbach's a. Validity was verified through factor analysis as well as analysis of correlations with four other relevant measures for psychosocial hazards assessment. All of them were previously widely applied in Poland by many researchers and approved for studying psychosocial environment at work, health and well-being in Polish employees.

Results: The Polish version of COPSOQ II is composed of 42 scales. The greater number of scales compared to the original version results from reliability analysis. As the original Variation scale was the only with unsatisfactory Cronbach's a so it was divided into two separate measures: Work Repetitiveness and Work Variety. Seven factors were identified and labelled as: Demands at Work, Organizational Relations, Physical Violence, Psychological Violence, Health and Well-being, Work Commitment and Development Perspectives, Relations within a Team. All associations were in the expected direction.

Tables: 5 • References: 32 • Full-text PDF: http://www.pjambp.com • Copyright $@ 2020$ Polish Aviation Medicine Society, ul. Krasińskiego 54/56, 01-755 Warsaw, license WIML • Indexation: Index Copernicus, Polish Ministry of Science and Higher Education 
Conclusions: The long COPSOQ II PL may be considered as a proper tool to study psychosocial hazards at work in Poland. However, further tests on work environments other than Prison Service are recommended.

Keywords: hazard management, work-related stress, risk management, COPSOQ, Prison Service, work-related health, occupational hazards, psychosocial hazards

\section{INTRODUCTION}

The Copenhagen Psychosocial Questionnaire (COPSOQ) was developed by the Danish $\mathrm{Na}$ tional Research Centre for Working Environment (NRCWE) [23].

Pejtersen at al. [23] decided that their tool will not be based on any singular theory, but will include many dimensions facilitating the performance of analyses on various levels: organizational, team and individual. The questionnaire makes it possible to study potential stressors at work as well as resources such as social support, feedback, commitment and well-being. The tool takes into account a comprehensive picture of the psychosocial working conditions, can be applied across a variety of work environments and is convenient for users. The tool is also identified to be appropriate to assess psychosocial hazards at work and is recommended in WHO publications [18]. Originally, three different length versions of the questionnaire were developed. Currently, the second version of the COPSOQ [23] is available in three different lengths. The longest COPSOQ II version (the so called long version) originally comprises 41 scales. 7 factors have been identified therein: demands at work, work structure and content, interpersonal relations and quality of leadership, work - individual relations, organizational culture, health and well-being, offensive behaviors [23]. One should also emphasize that even though the authors do not refer to any specific stress theory, COPSOQ II corresponds well with the Job Demands - Resources (JD-R) model [23]. Essentially all work aspects which, according to contemporary science, generate a psychosocial risk, are also included therein [23].

The Copenhagen Psychosocial Questionnaire (COPSOQ) is a widely accepted tool to assess psychosocial hazards at work, also for intervention purposes. The tool can be applied across a variety of work environments and is convenient for users $[18,21,23,25]$. One should also emphasize that even though the authors do not refer to any specific stress theory, COPSOQ corresponds well with the Job Demands - Resources (JD-R) model [2]. The COPSOQ was translated into a number of languages $[3,20,21,23,25]$, but there was no Polish adaptation of COPSOQ, even though some scales were translated for the needs of various research projects [31]. This paper presents the Polish adaptation of COPSOQ II's long version in Polish Prison Service Staff.

\section{MATERIAL AND METHODS}

The procedure for adapting the tool proceeded in accordance with the guidelines applicable to adapting tests designed to measure psychological health for WHO research needs across various countries [30]. To that end, questionnaire questions, possible responses and all test instructions were translated. After an expert's assessment which looked at the content and linguistic quality of the translation, a back-translation was performed, and pilot tests were carried out. The final version was used for validation in a relatively homogenous work environment, on a stratified sample, selected from staff and officers of the Prison Service [pl: Służba Więzienna] (SW), representative in terms of sex, workplace location and officer status. The used questionnaire was fully consistent with the original one in terms of items' content, response format as well as scoring rules Complete description of the original tool is available in another open-access paper [23].

The research was conducted in compliance with ethical standards in social sciences. The study was carried out individually, during periodic health tests of employees. The research was anonymous and voluntary, the participants were informed that they could resign from further participation in the research at any time without suffering any consequences. 
The obtained sample size of $\mathrm{N}=380$ was sufficient to keep the statistical error d below $5 \%$. Men $(77,9 \%)$ made up the majority of the research subjects. In terms of education, the largest group were individuals with at least a Master's degree (67,8\%). A further 10,8\% held Bachelor's degrees or completed a post-secondary school and the remaining part of the sample constituted individuals with secondary school education. Most of the research subjects were individuals in the 35-49 years old age bracket $(67,1 \%), 26,6 \%$ of the sample was composed of younger individuals (22-34 years old) and the remainder constituted the 5065 years old age bracket. All professional groups being part of the Prison Service were taken into account by the research. And thus, office and admin staff made up $29,5 \%$ of the sample, quartermasters $-7,4 \%$, security $-38,9 \%$, social rehabilitation (including: doctors, psychologists, educators) $-22,9 \%$ and teachers $-1,3 \%$. Almost the entire sample $(90,5 \%)$ was composed of officers.

Tab. 1. Reliability of COPSOQ II scales ( $\mathrm{N}=380)$.
Reliability and construct validity assessments were carried out within the scope of the validation. Reliability and construct validity assessment results are presented in subsequent parts of the paper. Reliability tests were limited to testing internal cohesion. Construct validity was assessed by way of a factor analysis and analysis of correlation with results obtained using four other tools: two which measured psychosocial working conditions and two which applied to the consequences of exposure to work related stress.

\section{RESULTS}

For clarity purposes, the presented results are grouped according to reliability and validity.

\section{Reliability}

The COPSOQ II PL questionnaire scales' reliability was estimated using the Cronbach's alpha coefficient. Means and standard deviations for given scales are shown alongside alpha values in table 1.

\begin{tabular}{|c|c|c|c|c|}
\hline Scale & Number of Items & M & SD & Cronbach's a \\
\hline Work pace & 3 & 65,00 & 19,38 & 0,880 \\
\hline Cognitive demands & 4 & 70,18 & 16,55 & 0,793 \\
\hline Emotional demands & 4 & 58,36 & 21,08 & 0,807 \\
\hline Demands for hiding emotions & 3 & 67,05 & 24,63 & 0,743 \\
\hline Possibilities for development (skill discretion) & 4 & 57,84 & 18,35 & 0,780 \\
\hline Variation & 2 & 43,21 & 19,07 & 0,394 \\
\hline Meaning of work & 3 & 67,49 & 21,16 & 0,846 \\
\hline Commitment to the workplace & 4 & 48,99 & 19,59 & 0,701 \\
\hline Role conflicts & 4 & 43,55 & 22,65 & 0,820 \\
\hline Quality of leadership & 4 & 52,42 & 24,61 & 0,927 \\
\hline Social support from colleagues & 3 & 54,99 & 19,08 & 0,801 \\
\hline Social support from supervisors & 3 & 50,53 & 25,12 & 0,889 \\
\hline Social community at work & 3 & 70,37 & 18,05 & 0,823 \\
\hline Job insecurity & 4 & 25,53 & 21,21 & 0,810 \\
\hline Job satisfaction & 4 & 40,89 & 16,71 & 0,811 \\
\hline Work-family conflict & 4 & 59,17 & 23,31 & 0,816 \\
\hline Sleeping troubles & 4 & 31,26 & 22,36 & 0,923 \\
\hline Burnout & 4 & 42,98 & 19,20 & 0,910 \\
\hline
\end{tabular}




\begin{tabular}{|c|c|c|c|c|}
\hline Depressive symptoms & 4 & 28,56 & 16,63 & 0,839 \\
\hline Somatic stress symptoms & 4 & 19,79 & 16,94 & 0,813 \\
\hline Cognitive stress symptoms & 4 & 24,74 & 17,78 & 0,892 \\
\hline Sexual harassment & 1 & 3,68 & 13,70 & - \\
\hline Threat of violence & 1 & 10,07 & 20,28 & - \\
\hline Physical violence & 1 & 6,38 & 18,97 & - \\
\hline Bullying & 1 & 9,02 & 19,93 & - \\
\hline Gossip and slander & 1 & 17,81 & 22,77 & - \\
\hline
\end{tabular}

M - mean; SD - standard deviation

\section{Validity}

In order to verify the validity of COPSOQ II, two methods out of the available construct validity tests [17] were used: factor analysis and correlation matrix.

\section{Factor analysis}

42 scales which make up the Polish COPSOQ II version were taken into account by the factor analysis, i.e. 40 scales from the original version and two further scales: "Job variation" and "Repeatability" which were established as a result of splitting the original "Variation" scale. Similar to validation of other COPSOQ II language versions, an exploratory factor analysis was performed on the Polish version as the COPSOQ does not refer to any specific theory and it was hypothesized that intercultural differences will be reflected in the structure of the tool. The KMO value of 0,933 and the Bartlett's test of sphericity: $\operatorname{chi} 2(861)=9054,854 ; p<0,001$ suggest that the EPA is entitled. The maximum likelihood method with an Oblmin rotation was used [23]. Kaiser's method and scree plot analysis
[32] were used in order to identify the number of factors. The results are shown in table 2 .

The detailed results of the performed factor analysis are shown in table 3.

Due to the use of Oblimin rotation, table 4 presents information on the correlation between the factors.

Tab. 2. Results of COPSOQ II PL factor analysis - Total Variance Explained.

\begin{tabular}{ccccc}
\hline Factor & \multicolumn{3}{c}{ Initial Eigenvalues } & $\begin{array}{c}\text { Rotation Sums of } \\
\text { Squared Loadings }\end{array}$ \\
\hline & Total & \% of Variance & Cumulative $\%$ & Total \\
\hline 1 & 12,97 & 30,87 & 30,87 & 3,82 \\
\hline 2 & 3,76 & 8,95 & 39,82 & 7,64 \\
\hline 3 & 3,07 & 7,32 & 47,14 & 6,89 \\
\hline 4 & 1,94 & 4,62 & 51,76 & 5,82 \\
\hline 5 & 1,62 & 3,85 & 55,60 & 5,82 \\
\hline 6 & 1,20 & 2,87 & 58,47 & 5,35 \\
\hline 7 & 1,13 & 2,69 & 61,16 & 5,70 \\
\hline
\end{tabular}

Extraction Method: Maximum Likelihood.

Tab. 3. Results of COPSOQ II PL factor analysis.

\begin{tabular}{|c|c|c|c|c|c|c|c|}
\hline Scale & $\begin{array}{l}\text { Factor 1: } \\
\text { Physical } \\
\text { violence }\end{array}$ & $\begin{array}{c}\text { Factor 2: } \\
\text { Organizational } \\
\text { Relations }\end{array}$ & $\begin{array}{l}\text { Factor 3: } \\
\text { Health and } \\
\text { well-being }\end{array}$ & $\begin{array}{l}\text { Factor 4: } \\
\text { Demands } \\
\text { at work }\end{array}$ & $\begin{array}{l}\text { Factor 5: } \\
\text { Psychological } \\
\text { violence }\end{array}$ & $\begin{array}{c}\text { Factor 6: } \\
\text { Work commitment } \\
\text { and development } \\
\text { perspectives }\end{array}$ & $\begin{array}{c}\text { Factor 7: } \\
\text { Relations within } \\
\text { a team }\end{array}$ \\
\hline Physical violence & 0,668 & & & & & & \\
\hline Sexual harassment & 0,356 & & & & & & \\
\hline Trust regarding management & & 0,829 & & & & & \\
\hline Quality of leadership & & 0,789 & & & & & \\
\hline Social support from supervisors & & 0,771 & & & & & \\
\hline Rewards (Recognition) & & 0,767 & & & & & \\
\hline
\end{tabular}


Orlak K. et al. - Polish adaptation...

\begin{tabular}{|c|c|c|c|c|c|c|c|}
\hline Scale & $\begin{array}{l}\text { Factor 1: } \\
\text { Physical } \\
\text { violence }\end{array}$ & $\begin{array}{c}\text { Factor 2: } \\
\text { Organizational } \\
\text { Relations }\end{array}$ & $\begin{array}{l}\text { Factor 3: } \\
\text { Health and } \\
\text { well-being }\end{array}$ & $\begin{array}{l}\text { Factor 4: } \\
\text { Demands } \\
\text { at work }\end{array}$ & $\begin{array}{c}\text { Factor 5: } \\
\text { Psychological } \\
\text { violence }\end{array}$ & $\begin{array}{c}\text { Factor 6: } \\
\text { Work commitment } \\
\text { and development } \\
\text { perspectives }\end{array}$ & $\begin{array}{c}\text { Factor 7: } \\
\text { Relations within } \\
\text { a team }\end{array}$ \\
\hline Predictability & & 0,703 & & & & & \\
\hline Role clarity & & 0,603 & & & & & \\
\hline Social inclusiveness & & 0,511 & & & & & \\
\hline Depressive symptoms & & & 0,842 & & & & \\
\hline Stress & & & 0,827 & & & & \\
\hline Cognitive stress & & & 0,824 & & & & \\
\hline Somatic stress & & & 0,781 & & & & \\
\hline Burnout & & & 0,776 & & & & \\
\hline Sleeping troubles & & & 0,746 & & & & \\
\hline Work-family conflict & & & 0,580 & & & & \\
\hline Self rated health & & & $-0,551$ & & & & \\
\hline Self-efficacy & & & $-0,425$ & & & & \\
\hline Work-family conflict & & & 0,347 & & & & \\
\hline Job insecurity & & & 0,343 & & & & \\
\hline Cognitive demands & & & & 0,838 & & & \\
\hline Work pace & & & & 0,797 & & & \\
\hline Emotional demands & & & & 0,692 & & & \\
\hline Quantitative demands & & & & 0,627 & & & \\
\hline Role conflicts & & & & 0,558 & & & \\
\hline Demands for hiding emotions & & & & 0,537 & & & \\
\hline Work repetitiveness & & & & $-0,324$ & & & \\
\hline Unpleasant teasing & & & & & 0,830 & & \\
\hline Bullying & & & & & 0,746 & & \\
\hline Gossip and slander & & & & & 0,636 & & \\
\hline Conflicts and quarrels & & & & & 0,562 & & \\
\hline $\begin{array}{l}\text { Possibilities for development (skill } \\
\text { discretion) }\end{array}$ & & & & & & 0,795 & \\
\hline Meaning of work & & & & & & 0,760 & \\
\hline Job satisfaction & & & & & & 0,675 & \\
\hline Commitment to the workplace & & & & & & 0,645 & \\
\hline Influence & & & & & & 0,544 & \\
\hline Work variety & & & & & & 0,420 & \\
\hline Social community at work & & & & & & & 0,797 \\
\hline Social support from colleagues & & & & & & & 0,688 \\
\hline Mutual trust between employees & & & & & & & 0,586 \\
\hline
\end{tabular}

Tab. 4. Results of COPSOQ II PL factor analysis - Factor Correlation Matrix.

\begin{tabular}{|c|c|c|c|c|c|c|c|}
\hline Factor & 1 & 2 & 3 & 4 & 5 & 6 & 7 \\
\hline 1 & 1,000 & $-0,152$ & 0,205 & 0,260 & 0,457 & 0,146 & $-0,175$ \\
\hline 2 & $-0,152$ & 1,000 & $-0,275$ & $-0,261$ & $-0,388$ & $-0,370$ & 0,463 \\
\hline 4 & 0,260 & $-0,261$ & 0,260 & 1,000 & 0,389 & 0,068 & $-0,268$ \\
\hline 5 & 0,457 & $-0,388$ & 0,178 & 0,389 & 1,000 & 0,154 & $-0,281$ \\
\hline 7 & $-0,175$ & 0,463 & $-0,256$ & $-0,268$ & $-0,281$ & $-0,355$ & 1,000 \\
\hline \multicolumn{8}{|c|}{ Extraction Method: Maximum Likelihood. } \\
\hline
\end{tabular}




\section{Analysis of correlations with other measures}

Four tools which satisfy the psychometric quality criteria were used for correlation analysis tests: two questionnaires to measure psychosocial working conditions, i.e. Psychosocial Working Conditions (PWP) [5] and Organizational Risk of Bullying (ORM) [29] as well as two tools which operationalize well-being: D. Goldberg's General Health Questionnaire (GHQ 30) $[11,19]$ and the Oldenburg Burnout Inventory (OLBI) questionnaire [1]. The analysis was carried out for all COPSOQ II PL scales. The adopted construct validity criteria are described in detail below. For greater analysis clarity they are presented according to given factors identified in the Polish version of the validated tool. Precise r-Pearson's correlation coefficient values subject to two-tailed significance criteria, stemming from the hypotheses stated below, are presented in table 5 .

\section{Scales part of Factor 1: "Physical violence"}

The following scales make up the "Physical violence" factor:

1. "Threats of violence", which describes the sense of threat of violence, including physical violence at the workplace.

2. "Physical violence", which refers to experiencing physical violence.

3. "Sexual harassment", which refers to exposure to unwanted sexual attention.

All of these refer to a threat of bodily inviolability infringement. Construct validity of the scales which constitute the "Physical violence" factor was assessed on the basis of convergence of results for these scales with the occurrence of health disorders and burnout indicators. Such an approach is based on numerous empirical studies which show that various forms of violence at work, which include sexual harassment, are linked with negative consequences of symptoms of distress, symptoms of depression and anxiety, sleeping troubles, somatic problems or burnout $[7,10]$. The obtained Pearson's $r$ coefficients are shown in table 5.

\section{Scales which make up Factor 2: "Organizational relations"}

8 scales make up the "Organizational relations" factor, i.e.:

1. "Justice" which applies to the perceived respect and equal rights of employees at the workplace.

2. "Trust regarding management", which refers to the reliability of information and the sense of security in relations with superiors.
3. "Quality of leadership", which refers to an assessment of superiors in terms of selected leadership skills.

4. "Social support from supervisors", which describes the perceived potential and actual help from a superior.

5. "Recognition" which applies to the personal experience of respect and equal rights in the workplace.

6. "Predictability", which means that the required information pertaining to work tasks and organization is passed on.

7. "Role clarity", reflecting certainty as to the scope of duties, targets and work evaluation criteria.

8. "Social inclusiveness", which refers to managing diversity at the workplace.

Validity tests of COPSOQ II PL scales which make up the "Organizational relations" factor were performed by correlating these scales with the general result of the GHQ $30[11,19]$ questionnaire, burnout indicators measured using the OLBI [1] questionnaire as well as three scales from the ORM [29] questionnaire: "Clarity of roles and control", "Relations with the direct superior" and "Leadership", as well as two scales from the PWP [5] questionnaire which measured control (autonomy and participation) as well as the noticed support from superiors. Here, a negative correlation was assumed between COPSOQ II PL scales and the scales which measure pathologies at the workplace (ORM scales) [29] and negative consequences of occupational stress (GHQ 30 and OLBI) $[1,11,19]$ and a positive correlation with resources ("Social support from supervisor" and "Control"). These assumptions are cohesive with the JD-R [2] theory as well as empirical studies [18]. Table 5 depicts the correlation results.

The scales part of Factor 3: "Health and well-being" The "Health and well-being" factor comprises 11 COPSOQ II PL scales, including:

1. "Depressive symptoms", measured using anhedonia and bad mood symptoms.

2. "Stress", which describes the behavioral and emotional stress symptoms.

3. "Cognitive stress symptoms", which refers to the reactive problems with memory and attention span.

4. "Somatic stress symptoms", which refers to the physical stress related ailments.

5. "Burnout", which measures physical and emotional exhaustion.

6. "Sleeping troubles", which measures sleeping problems.

7. "Work-family conflict", which applies to the impact of work structure on private life. 
8. "General health perception", which makes it possible to measure the subjective rating of one's own state of health.

9. "Self-efficacy", which refers to the self-assessment of one's own capacity.

10. "Family-work conflict", pertaining to the impact of an individual's private situation on their professional life.

11. "Job insecurity", which means the degree to which employment conditions are seen as stable.

The particular scales part of the "Health and well-being" factor were correlated with the results of GHQ $30[11,19]$ and OLBI [1]. It was assumed that the COPSOQ II PL scales which measure disorders ("Sleeping troubles", "Burnout", "Stress", "Depressive symptoms", "Somatic stress symptoms", "Cognitive stress symptoms") will be positively correlated with the results of the aforementioned tools, whereas scales which measure well-being ("General health perception" and "Self-efficacy") will show negative correlations. These assumptions are reflected in the literature on the subject $[18,27]$. The "Job insecurity" scale was additionally correlated with a scale of the same name that is a part of the ORM [29] questionnaire, assuming a positive correlation between the two scales. Verification results of hypotheses pertaining to the measures of well-being taken into account by COPSOQ II PL are shown in table 5 .

\section{The scales part of Factor 4: Demands at work}

The "Demands at work" factor comprises the following scales:

1. "Cognitive demands", which pertains to job aspects such as decision making, creativity and attention.

2. "Work pace", which refers to aspects such as time pressure or imposed work rhythm.

3. "Emotional demands", which applies to the need to engage emotions into the task at hand.

4. "Quantitative demands" - describes the degree to which work load reflects the available time.

5. "Role conflicts", pertaining to the requirement to function under conflicting demands, conflicting interests and to solve ethical dilemmas.

6. "Demands for hiding emotions", which means the inability to express emotions freely.

7. "Repeatability", which applies to the degree to which work is routine.

It was assumed that the results obtained for scales which make up the "Demands at work" factor should be positively correlated with the results of other questionnaires which measure workplace demands. The demands scale from the PWP [5] questionnaire was used to test this hypothesis. Furthermore, with reference to the JD-R [2] model, the COPSOQ II PL scales which measure demands were expected to be convergent with the results in "Exhaustion" and "Disengagement" from the OLBI [1] questionnaire. In accordance to literature $[16,22,26]$, positive correlations were assumed between demands and the occurrence of mental health disorders measured by the GHQ-30 [11]. A detailed list of $r$-Pearson's coefficients obtained whilst verifying the above hypotheses is shown in table 5. Additionally, a correlation analysis between the "Repeatability" scale and monotony-diversity measure in the PWP questionnaire was performed. That analysis showed a positive relation between the tested variables $(r=0,305, p>001)$.

\section{The scales part of Factor 5: Psychological violence}

The "Psychological violence" factor comprises the following scales:

1. "Unpleasant teasing" which pertains to the exposure to teasing at the workplace.

2. "Bullying", which makes it possible to measure the exposure to harassment and threats at the workplace.

3. "Gossip and slander", which reflects a subjective feeling of being the subject of insinuations at work.

4. "Conflicts and quarrels", pertaining to participation in conflicts at work.

The construct validity of the scales which constitute the "Psychological violence" factor was assessed on the basis of convergence of results for these scales with the occurrence of health disorders and burnout indicators. The hypotheses are based on numerous empirical studies which show that bullying and other forms of psychological violence at the workplace are correlated with the negative consequences of symptoms of depression and anxiety, somatic problems or burnout [9]. Furthermore, the convergence of COPSOQ II PL scales which measure the different forms of violence with the ORM [29] questionnaire results was considered to speak for their accuracy. This assumption is further supported by results of tests on individual and organizational bullying correlates. The obtained Pearson's $r$ correlation coefficients are shown in table 5 .

\section{The scales part of Factor 6: Work commitment and development perspectives}

The "Work commitment and development perspectives" factor includes 6 scales, i.e.:

1. "Possibilities for development", which pertains to making use of and shaping professional skills.

2. "Meaning of work", which measures the subjective feeling of the importance of the performed work. 
3. "Job satisfaction", which refers to the subjective satisfaction derived from working.

4. "Commitment to the workplace", reflecting the degree to which a person shares and approves their workplace culture.

5. "Influence", used to measure the freedom of decision making.

6. "Job variation", which allows for a determination of job diversity.

Thus, one may venture to say that the "Commitment and development perspectives" factor measures the following:

1) job resources, such as the ability to control work, participation in decision making processes, feedback on the performed work, meaning of work, diversity of performed tasks and possibilities for development $[6,9]$ and

2) the employee's attitudes towards their job (job satisfaction, commitment to the workplace), which remain in a close relation with the said resources [24].

Hence, according to the JD-R[2] model, they should be related to health and burnout. And the correlation should be negative: the higher the signs of commitment, the less health problems and burnout symptoms. Additionally, positive relations with other resource measures should also manifest themselves, e.g. the degree of control from the PWP [5] questionnaire.

\section{The scales part of Factor 7: Relations in a team}

The "Relations in a team" factor comprises the following scales:

1. "Social community at work", which applies to the atmosphere at the workplace.

2. "Social support from colleagues", which describes experiencing help from colleagues.

3. "Mutual trust between employees", which defines the level of openness and trust in relations with colleagues.

Quality relations at work are considered to be social resources, and thus in accordance with the JD-R[2] theory, high scores in corresponding COPSOQ II PL scales should exhibit a negative correlation with indicators pointing to deteriorating health and burnout. They should also manifest a positive correlation with other tools for measuring job resources associated with colleagues, such as results of "Support from colleagues" in the PWP [5] questionnaire or shortages thereof, such as the "Social atmosphere" from the ORM [29] questionnaire. Results of the conducted correlation analysis are shown in table 5 .

Tab. 5. Correlations between COPSOQ II PL scales which make up the "Physical violence," "Organizational relations”," well-being,"“Demands at work","Psychological violence,"“'Work commitment and development perspectives," "Relations in team" and other tools (Goldberg's GHQ 30 General state of health questionnaire, Oldenburg Burnout Inventory (OLBI) questionnaire, Organizational Risk of Bullying (ORM) and Psychosocial Working Conditions (PWP) questionnaires).

\begin{tabular}{|c|c|c|c|c|c|c|c|c|c|c|c|c|c|c|}
\hline & 气ूँ & 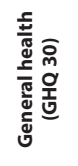 & 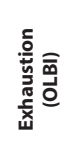 & 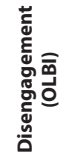 & 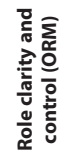 & 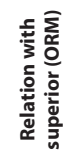 & 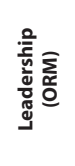 & 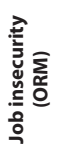 & 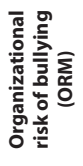 & 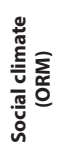 & 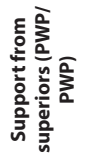 & 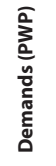 & $\begin{array}{l}\bar{a} \\
30 \\
0 \\
\overline{0} \\
\vdots \\
0 \\
0\end{array}$ & 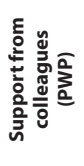 \\
\hline \multirow{3}{*}{ 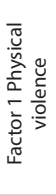 } & $\begin{array}{l}\text { Threats of } \\
\text { violence }\end{array}$ & $.256^{* *}$ & $.178^{* *}$ & $.243^{* *}$ & N/A & $\mathrm{N} / \mathrm{A}$ & $\mathrm{N} / \mathrm{A}$ & $\mathrm{N} / \mathrm{A}$ & $\mathrm{N} / \mathrm{A}$ & $\mathrm{N} / \mathrm{A}$ & $\mathrm{N} / \mathrm{A}$ & $\mathrm{N} / \mathrm{A}$ & N/A & $\mathrm{N} / \mathrm{A}$ \\
\hline & $\begin{array}{l}\text { Physical } \\
\text { violence }\end{array}$ & $.172^{* *}$ & 0.092 & $.197^{* *}$ & N/A & N/A & N/A & N/A & N/A & N/A & $\mathrm{N} / \mathrm{A}$ & N/A & N/A & N/A \\
\hline & $\begin{array}{l}\text { Sexual ha- } \\
\text { rassment }\end{array}$ & $.128^{*}$ & $.102^{*}$ & $.169^{* *}$ & N/A & N/A & N/A & $\mathrm{N} / \mathrm{A}$ & N/A & $\mathrm{N} / \mathrm{A}$ & $\mathrm{N} / \mathrm{A}$ & N/A & N/A & $\mathrm{N} / \mathrm{A}$ \\
\hline \multirow{8}{*}{ 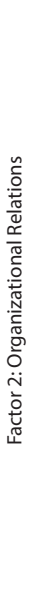 } & $\begin{array}{l}\text { Justice and } \\
\text { respect }\end{array}$ &,$- 244^{* *}$ & $-.412^{* *}$ & $-.524 * *$ & $-.622^{* *}$ & $-.684^{* *}$ & $-.720 * *$ & $\mathrm{~N} / \mathrm{A}$ & $\mathrm{N} / \mathrm{A}$ & $\mathrm{N} / \mathrm{A}$ & $.693^{* *}$ & $\mathrm{~N} / \mathrm{A}$ & N/A & $\mathrm{N} / \mathrm{A}$ \\
\hline & $\begin{array}{l}\text { Trust } \\
\text { regarding } \\
\text { manage- } \\
\text { ment }\end{array}$ & $-.292^{* *}$ & $-.439 * *$ & $-.493^{* *}$ & $-.605^{* *}$ & $-.726^{* *}$ & $-.697^{* *}$ & N/A & N/A & N/A & $.731^{* *}$ & N/A & N/A & N/A \\
\hline & $\begin{array}{l}\text { Quality of } \\
\text { leadership }\end{array}$ & $-.186^{* *}$ & $-.370^{* *}$ & $-.477^{* *}$ & $-.597^{* *}$ & $-.725^{* *}$ & $-.739^{* *}$ & N/A & N/A & $\mathrm{N} / \mathrm{A}$ & $.705^{* *}$ & N/A & N/A & $\mathrm{N} / \mathrm{A}$ \\
\hline & $\begin{array}{l}\text { Social sup- } \\
\text { port from } \\
\text { supervisors }\end{array}$ & $-.208^{* *}$ & $-.355^{* *}$ & $-.397^{* *}$ & $-.544^{* *}$ & $-.701^{* *}$ & $-.670^{* *}$ & N/A & $\mathrm{N} / \mathrm{A}$ & N/A & $.687^{* *}$ & N/A & N/A & $\mathrm{N} / \mathrm{A}$ \\
\hline & $\begin{array}{l}\text { Rewards } \\
\text { (Recogni- } \\
\text { tion) }\end{array}$ & $-.243^{* *}$ & $-.457^{* *}$ & $-.497^{* *}$ & $-.579^{* *}$ & $-.701^{* *}$ & $-.669^{* *}$ & $\mathrm{~N} / \mathrm{A}$ & $\mathrm{N} / \mathrm{A}$ & $\mathrm{N} / \mathrm{A}$ & $.714^{* *}$ & N/A & N/A & $\mathrm{N} / \mathrm{A}$ \\
\hline & $\begin{array}{l}\text { Predicta- } \\
\text { bility }\end{array}$ & $-.249^{* *}$ & $-.424^{* *}$ & $-.522^{* *}$ & $-.607^{* *}$ & $-.610^{* *}$ & $-.617^{* *}$ & N/A & N/A & $\mathrm{N} / \mathrm{A}$ & $.619^{* *}$ & N/A & N/A & $\mathrm{N} / \mathrm{A}$ \\
\hline & Role clarity & $-.261^{* *}$ & $-.353^{* *}$ & $-.436^{* *}$ & $-.606^{* *}$ & $-.511^{* *}$ & $-.562^{* *}$ & $\mathrm{~N} / \mathrm{A}$ & $\mathrm{N} / \mathrm{A}$ & $\mathrm{N} / \mathrm{A}$ & $.534^{* *}$ & N/A & N/A & $\mathrm{N} / \mathrm{A}$ \\
\hline & $\begin{array}{l}\text { Social inc- } \\
\text { lusiveness }\end{array}$ & $-.116^{*}$ & $-.213^{* *}$ & $-.260^{* *}$ & $-.307^{* *}$ & $-.350^{* *}$ & $-.379^{* *}$ & $\mathrm{~N} / \mathrm{A}$ & $\mathrm{N} / \mathrm{A}$ & $\mathrm{N} / \mathrm{A}$ & $.310^{* *}$ & N/A & $\mathrm{N} / \mathrm{A}$ & N/A \\
\hline
\end{tabular}


Orlak K. et al. - Polish adaptation...

\begin{tabular}{|c|c|c|c|c|c|c|c|c|c|c|c|c|c|c|}
\hline & $\frac{0}{\text { ฝ̆ }}$ & 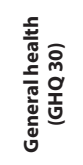 & 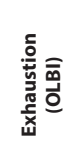 & 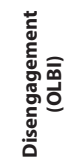 & 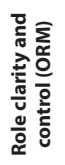 & 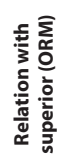 & 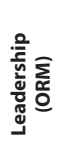 & 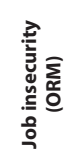 & 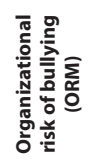 & 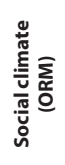 & 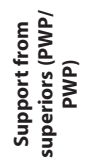 & 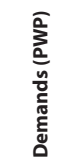 & 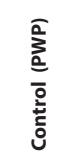 & 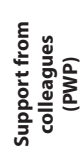 \\
\hline \multirow{11}{*}{ 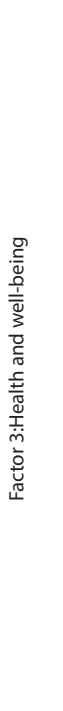 } & $\begin{array}{l}\text { Depressive } \\
\text { symptoms }\end{array}$ & $.630^{* *}$ & $.579^{* *}$ & $.457^{* *}$ & $\mathrm{~N} / \mathrm{A}$ & $\mathrm{N} / \mathrm{A}$ & $\mathrm{N} / \mathrm{A}$ & $.349^{* *}$ & $\mathrm{~N} / \mathrm{A}$ & $\mathrm{N} / \mathrm{A}$ & $\mathrm{N} / \mathrm{A}$ & N/A & N/A & $\mathrm{N} / \mathrm{A}$ \\
\hline & Stress & $.639^{* *}$ & $.671^{* *}$ & $.556^{* *}$ & $\mathrm{~N} / \mathrm{A}$ & $\mathrm{N} / \mathrm{A}$ & $\mathrm{N} / \mathrm{A}$ & $.315^{* *}$ & $\mathrm{~N} / \mathrm{A}$ & $\mathrm{N} / \mathrm{A}$ & $\mathrm{N} / \mathrm{A}$ & $\mathrm{N} / \mathrm{A}$ & $\mathrm{N} / \mathrm{A}$ & $\mathrm{N} / \mathrm{A}$ \\
\hline & $\begin{array}{l}\text { Cognitive } \\
\text { stress }\end{array}$ & $.605^{* *}$ & $.598^{* *}$ & $.455^{* *}$ & $\mathrm{~N} / \mathrm{A}$ & $\mathrm{N} / \mathrm{A}$ & $\mathrm{N} / \mathrm{A}$ & $.298^{* *}$ & $\mathrm{~N} / \mathrm{A}$ & $\mathrm{N} / \mathrm{A}$ & $\mathrm{N} / \mathrm{A}$ & N/A & N/A & $\mathrm{N} / \mathrm{A}$ \\
\hline & $\begin{array}{l}\text { Somatic } \\
\text { stress }\end{array}$ & $.531^{* *}$ & $.556^{* *}$ & $.408^{* *}$ & $\mathrm{~N} / \mathrm{A}$ & $\mathrm{N} / \mathrm{A}$ & $\mathrm{N} / \mathrm{A}$ & $.293^{* *}$ & $\mathrm{~N} / \mathrm{A}$ & $\mathrm{N} / \mathrm{A}$ & $\mathrm{N} / \mathrm{A}$ & N/A & N/A & N/A \\
\hline & Burnout & $.572^{* *}$ & $.666^{* *}$ & $.553^{* *}$ & N/A & N/A & N/A & $.257^{* *}$ & $\mathrm{~N} / \mathrm{A}$ & $\mathrm{N} / \mathrm{A}$ & $\mathrm{N} / \mathrm{A}$ & N/A & N/A & $\mathrm{N} / \mathrm{A}$ \\
\hline & $\begin{array}{l}\text { Sleeping } \\
\text { troubles }\end{array}$ & $.532^{* *}$ & $.537^{* *}$ & $.379^{* *}$ & $\mathrm{~N} / \mathrm{A}$ & $\mathrm{N} / \mathrm{A}$ & $\mathrm{N} / \mathrm{A}$ & $.298^{* *}$ & N/A & $N / A$ & $\mathrm{~N} / \mathrm{A}$ & $\mathrm{N} / \mathrm{A}$ & N/A & N/A \\
\hline & $\begin{array}{l}\text { Work-fami- } \\
\text { ly conflict }\end{array}$ & $.506^{* *}$ & $.616^{* *}$ & $.459^{* *}$ & $\mathrm{~N} / \mathrm{A}$ & $\mathrm{N} / \mathrm{A}$ & $N / A$ & $.367^{* *}$ & $\mathrm{~N} / \mathrm{A}$ & $N / A$ & N/A & N/A & N/A & $\mathrm{N} / \mathrm{A}$ \\
\hline & $\begin{array}{l}\text { Self rated } \\
\text { health }\end{array}$ & $-.382^{* *}$ & $-.521^{* *}$ & $-.390^{* *}$ & $\mathrm{~N} / \mathrm{A}$ & $\mathrm{N} / \mathrm{A}$ & $\mathrm{N} / \mathrm{A}$ & $-.171^{* *}$ & $\mathrm{~N} / \mathrm{A}$ & $\mathrm{N} / \mathrm{A}$ & N/A & $\mathrm{N} / \mathrm{A}$ & N/A & N/A \\
\hline & $\begin{array}{l}\text { Self-effi- } \\
\text { cacy }\end{array}$ & $-.335^{* *}$ & $-.374^{* *}$ & $-.250^{* *}$ & $\mathrm{~N} / \mathrm{A}$ & $\mathrm{N} / \mathrm{A}$ & $\mathrm{N} / \mathrm{A}$ & $-.206^{* *}$ & $\mathrm{~N} / \mathrm{A}$ & $\mathrm{N} / \mathrm{A}$ & $\mathrm{N} / \mathrm{A}$ & $\mathrm{N} / \mathrm{A}$ & N/A & $\mathrm{N} / \mathrm{A}$ \\
\hline & $\begin{array}{l}\text { Work-fami- } \\
\text { ly conflict }\end{array}$ & $.319^{* *}$ & $.247^{* *}$ & $.230^{* *}$ & $\mathrm{~N} / \mathrm{A}$ & $\mathrm{N} / \mathrm{A}$ & $\mathrm{N} / \mathrm{A}$ & $.227^{* *}$ & $\mathrm{~N} / \mathrm{A}$ & $\mathrm{N} / \mathrm{A}$ & $\mathrm{N} / \mathrm{A}$ & N/A & N/A & N/A \\
\hline & $\begin{array}{l}\text { Job inse- } \\
\text { curity }\end{array}$ & $.297^{* *}$ & $.252^{* *}$ & $.148^{* *}$ & $\mathrm{~N} / \mathrm{A}$ & $\mathrm{N} / \mathrm{A}$ & $\mathrm{N} / \mathrm{A}$ & $.395^{* *}$ & N/A & $N / A$ & N/A & $\mathrm{N} / \mathrm{A}$ & $\mathrm{N} / \mathrm{A}$ & N/A \\
\hline \multirow{7}{*}{ 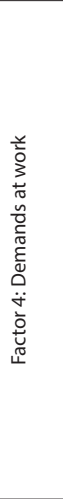 } & $\begin{array}{l}\text { Cognitive } \\
\text { demands }\end{array}$ & $.264^{* *}$ & $.224^{* *}$ & $.224^{* *}$ & $\mathrm{~N} / \mathrm{A}$ & $\mathrm{N} / \mathrm{A}$ & $\mathrm{N} / \mathrm{A}$ & $\mathrm{N} / \mathrm{A}$ & N/A & $\mathrm{N} / \mathrm{A}$ & $\mathrm{N} / \mathrm{A}$ & $.557^{* *}$ & $\mathrm{~N} / \mathrm{A}$ & $\mathrm{N} / \mathrm{A}$ \\
\hline & Work pace & $.270^{* *}$ & $.354^{* *}$ & $.356^{* *}$ & $\mathrm{~N} / \mathrm{A}$ & $\mathrm{N} / \mathrm{A}$ & $\mathrm{N} / \mathrm{A}$ & $\mathrm{N} / \mathrm{A}$ & $\mathrm{N} / \mathrm{A}$ & $N / A$ & N/A & $.401^{* *}$ & N/A & $\mathrm{N} / \mathrm{A}$ \\
\hline & $\begin{array}{l}\text { Emotional } \\
\text { demands }\end{array}$ & $.347^{* *}$ & $.336^{* *}$ & $.316^{* *}$ & $\mathrm{~N} / \mathrm{A}$ & $\mathrm{N} / \mathrm{A}$ & $\mathrm{N} / \mathrm{A}$ & $\mathrm{N} / \mathrm{A}$ & N/A & $N / A$ & $\mathrm{~N} / \mathrm{A}$ & $.445^{* *}$ & N/A & N/A \\
\hline & $\begin{array}{c}\text { Quan- } \\
\text { titative } \\
\text { demands }\end{array}$ & $.348^{* *}$ & $.533^{* *}$ & $.488^{* *}$ & $\mathrm{~N} / \mathrm{A}$ & $\mathrm{N} / \mathrm{A}$ & N/A & $\mathrm{N} / \mathrm{A}$ & $\mathrm{N} / \mathrm{A}$ & $\mathrm{N} / \mathrm{A}$ & N/A & $.325^{* *}$ & N/A & $\mathrm{N} / \mathrm{A}$ \\
\hline & $\begin{array}{c}\text { Role } \\
\text { conflicts }\end{array}$ & $.341^{* *}$ & $.414^{* *}$ & $.442^{* *}$ & $\mathrm{~N} / \mathrm{A}$ & $\mathrm{N} / \mathrm{A}$ & $\mathrm{N} / \mathrm{A}$ & $\mathrm{N} / \mathrm{A}$ & $\mathrm{N} / \mathrm{A}$ & $\mathrm{N} / \mathrm{A}$ & $\mathrm{N} / \mathrm{A}$ & $.382^{* *}$ & $\mathrm{~N} / \mathrm{A}$ & $\mathrm{N} / \mathrm{A}$ \\
\hline & $\begin{array}{l}\text { Demands } \\
\text { for hiding } \\
\text { emotions }\end{array}$ & $.232^{* *}$ & $.186^{* *}$ & $.242^{* *}$ & $\mathrm{~N} / \mathrm{A}$ & $\mathrm{N} / \mathrm{A}$ & N/A & $\mathrm{N} / \mathrm{A}$ & $\mathrm{N} / \mathrm{A}$ & $\mathrm{N} / \mathrm{A}$ & N/A & $.298^{* *}$ & N/A & $\mathrm{N} / \mathrm{A}$ \\
\hline & $\begin{array}{l}\text { Work repe- } \\
\text { titiveness }\end{array}$ & $.200^{* *}$ & $.219^{* *}$ & $.293^{* *}$ & $\mathrm{~N} / \mathrm{A}$ & $\mathrm{N} / \mathrm{A}$ & $\mathrm{N} / \mathrm{A}$ & $\mathrm{N} / \mathrm{A}$ & $\mathrm{N} / \mathrm{A}$ & $N / A$ & $\mathrm{~N} / \mathrm{A}$ & 0.066 & N/A & N/A \\
\hline \multirow{4}{*}{ 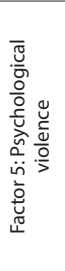 } & $\begin{array}{c}\text { Unpleasant } \\
\text { teasing }\end{array}$ & $.330^{* *}$ & $.285^{* *}$ & $.305^{* *}$ & N/A & $\mathrm{N} / \mathrm{A}$ & N/A & $\mathrm{N} / \mathrm{A}$ & $.447^{* *}$ & $N / A$ & $\mathrm{~N} / \mathrm{A}$ & N/A & N/A & N/A \\
\hline & Bullying & $.234^{* *}$ & $.234^{* *}$ & $.288^{* *}$ & $\mathrm{~N} / \mathrm{A}$ & $\mathrm{N} / \mathrm{A}$ & $\mathrm{N} / \mathrm{A}$ & $\mathrm{N} / \mathrm{A}$ & $.465^{* *}$ & $\mathrm{~N} / \mathrm{A}$ & $\mathrm{N} / \mathrm{A}$ & $\mathrm{N} / \mathrm{A}$ & N/A & $\mathrm{N} / \mathrm{A}$ \\
\hline & $\begin{array}{l}\text { Gossip and } \\
\text { slander }\end{array}$ & $.314^{* *}$ & $.311^{* *}$ & $.377^{* *}$ & $\mathrm{~N} / \mathrm{A}$ & $\mathrm{N} / \mathrm{A}$ & $\mathrm{N} / \mathrm{A}$ & $\mathrm{N} / \mathrm{A}$ & $.428^{* *}$ & $\mathrm{~N} / \mathrm{A}$ & N/A & N/A & N/A & $\mathrm{N} / \mathrm{A}$ \\
\hline & $\begin{array}{l}\text { Conflicts } \\
\text { and } \\
\text { quarrels }\end{array}$ & $.312^{* *}$ & $.324^{* *}$ & $.350^{* *}$ & $\mathrm{~N} / \mathrm{A}$ & $\mathrm{N} / \mathrm{A}$ & $\mathrm{N} / \mathrm{A}$ & N/A & $.375^{* *}$ & $\mathrm{~N} / \mathrm{A}$ & $\mathrm{N} / \mathrm{A}$ & $\mathrm{N} / \mathrm{A}$ & $\mathrm{N} / \mathrm{A}$ & $\mathrm{N} / \mathrm{A}$ \\
\hline \multirow{6}{*}{ 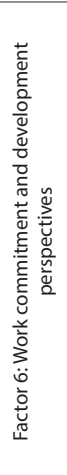 } & $\begin{array}{l}\text { Possibi- } \\
\text { lities for } \\
\text { develop- } \\
\text { ment (skill } \\
\text { discretion) }\end{array}$ & $-.145^{* *}$ & $-.312^{* *}$ & $-.456^{* *}$ & $\mathrm{~N} / \mathrm{A}$ & $\mathrm{N} / \mathrm{A}$ & $\mathrm{N} / \mathrm{A}$ & N/A & $\mathrm{N} / \mathrm{A}$ & $\mathrm{N} / \mathrm{A}$ & $\mathrm{N} / \mathrm{A}$ & $\mathrm{N} / \mathrm{A}$ & $.443^{* *}$ & $\mathrm{~N} / \mathrm{A}$ \\
\hline & $\begin{array}{l}\text { Meaning of } \\
\text { work }\end{array}$ & $-.324^{* *}$ & $-.439 * *$ & $-.623^{* *}$ & $\mathrm{~N} / \mathrm{A}$ & $\mathrm{N} / \mathrm{A}$ & N/A & N/A & N/A & $\mathrm{N} / \mathrm{A}$ & N/A & $\mathrm{N} / \mathrm{A}$ & $.528^{* *}$ & $\mathrm{~N} / \mathrm{A}$ \\
\hline & $\begin{array}{l}\text { Job satis- } \\
\text { faction }\end{array}$ & $-.387^{* *}$ & $-.541^{* *}$ & $-.640^{* *}$ & $\mathrm{~N} / \mathrm{A}$ & $\mathrm{N} / \mathrm{A}$ & $\mathrm{N} / \mathrm{A}$ & $\mathrm{N} / \mathrm{A}$ & $\mathrm{N} / \mathrm{A}$ & $\mathrm{N} / \mathrm{A}$ & N/A & N/A & $.580^{* *}$ & $\mathrm{~N} / \mathrm{A}$ \\
\hline & $\begin{array}{l}\text { Commit- } \\
\text { ment to the } \\
\text { workplace }\end{array}$ & $-.350^{* *}$ & $-.465^{* *}$ & $-.594^{* *}$ & $\mathrm{~N} / \mathrm{A}$ & $\mathrm{N} / \mathrm{A}$ & $\mathrm{N} / \mathrm{A}$ & N/A & $\mathrm{N} / \mathrm{A}$ & $\mathrm{N} / \mathrm{A}$ & N/A & $\mathrm{N} / \mathrm{A}$ & $.541^{* *}$ & $\mathrm{~N} / \mathrm{A}$ \\
\hline & Influence & $-.188^{* *}$ & $-.281^{* *}$ & $-.332^{* *}$ & $\mathrm{~N} / \mathrm{A}$ & $\mathrm{N} / \mathrm{A}$ & $\mathrm{N} / \mathrm{A}$ & $\mathrm{N} / \mathrm{A}$ & N/A & $N / A$ & N/A & N/A & $.458^{* *}$ & N/A \\
\hline & $\begin{array}{c}\text { Work } \\
\text { variety }\end{array}$ & $-.178^{* *}$ & $-.246^{* *}$ & $-.264^{* *}$ & $\mathrm{~N} / \mathrm{A}$ & $\mathrm{N} / \mathrm{A}$ & $\mathrm{N} / \mathrm{A}$ & $\mathrm{N} / \mathrm{A}$ & N/A & $\mathrm{N} / \mathrm{A}$ & $\mathrm{N} / \mathrm{A}$ & N/A & $.227^{* *}$ & $\mathrm{~N} / \mathrm{A}$ \\
\hline
\end{tabular}




\begin{tabular}{|c|c|c|c|c|c|c|c|c|c|c|c|c|c|c|}
\hline & ڤ̆ & 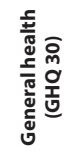 & 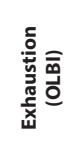 & 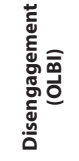 & 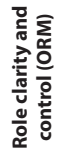 & 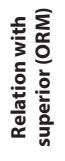 & 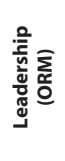 & 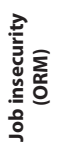 & 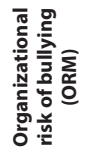 & 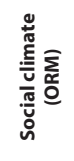 & 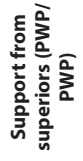 & 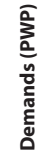 & 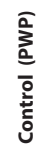 & 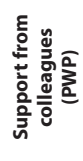 \\
\hline \multirow{3}{*}{ 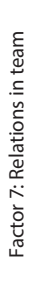 } & $\begin{array}{c}\text { Social } \\
\text { community } \\
\text { at work }\end{array}$ & $-.257^{* *}$ & $-.362^{* *}$ & $-.405^{* *}$ & $\mathrm{~N} / \mathrm{A}$ & $\mathrm{N} / \mathrm{A}$ & $\mathrm{N} / \mathrm{A}$ & $\mathrm{N} / \mathrm{A}$ & N/A & $-.523^{* *}$ & N/A & $\mathrm{N} / \mathrm{A}$ & N/A & $.592^{* *}$ \\
\hline & $\begin{array}{l}\text { Social sup- } \\
\text { port from } \\
\text { colleagues }\end{array}$ & $-.118^{*}$ & $-.288^{* *}$ & $-.286^{* *}$ & $\mathrm{~N} / \mathrm{A}$ & $\mathrm{N} / \mathrm{A}$ & $\mathrm{N} / \mathrm{A}$ & N/A & N/A & $-.337^{* *}$ & N/A & $\mathrm{N} / \mathrm{A}$ & N/A & $.562^{* *}$ \\
\hline & $\begin{array}{c}\text { Mutual } \\
\text { trust } \\
\text { between } \\
\text { employees }\end{array}$ & $-.313^{* *}$ & $-.355^{* *}$ & $-.446^{* *}$ & $\mathrm{~N} / \mathrm{A}$ & $\mathrm{N} / \mathrm{A}$ & $\mathrm{N} / \mathrm{A}$ & $\mathrm{N} / \mathrm{A}$ & $\mathrm{N} / \mathrm{A}$ & $-.560^{* *}$ & N/A & $\mathrm{N} / \mathrm{A}$ & N/A & $.551^{* *}$ \\
\hline
\end{tabular}

* $p<0.05 * * p<0.01 ; N / A-$ non applicable;

\section{DISCUSSION}

The COPSOQ II PL is both reliable as well as valid, despite being structurally different from the original version.

\section{Reliability}

The reliability of scales may be considered to be satisfactory as the Cronbach's a coefficient is more than 0,7 [28]. The only scale which failed to reach such a value for this coefficient was "Job variation", where $a=0,394$. It should also be pointed out that the reliability of that scale was also low in its original COPSOQ II questionnaire version, with $a=0,5$ [23]. The following items are part of the scale: "Is your job varied?" and "In your job are you frequently forced to repeat the same actions?". The content of these items and the low Cronbach's a coefficient value shows the need to split the scale into two, both one-item. The first scale was named "Job variation" (Is your job varied?) and the second "Repeatability" (In your job are you frequently forced to repeat the same actions?). The new scales were used during validity analysis. The Cronbach's a coefficient value is satisfactory for all other scales. Its values are between 0,701 (commitment to the workplace) to 0,927 (Quality of leadership). Thus, the tool should be considered to be reliable, and as such it qualifies for further analyses.

\section{Validity}

Both analyses carried out as part of construct validity tests yielded satisfactory results.

\section{Factor analysis}

7 factors were identified in the Polish COPSOQ II version, with different scales than those in the original.

The factors identified in the Polish version remain cohesive and theoretically valid. Apart from all the scales in the original version, the "Job de- mands" factor in the Polish version also includes two additional scales: "Role conflicts" and "Repeatability". In tests carried out on Polish employees, role conflicts remains a dimension of demands associated with a job, as shown by Cieślak and Widerszal-Bazyl [5] in papers on the Psychosocial Working Conditions (PWP) questionnaire. Similarly, monotony (as opposed to diversity) in the PWP questionnaire is treated as a demand. It should be noted that in the COPSOQ II PL validity sample, "Repeatability" was part of the "Demands at work" factor, albeit with a negative sign, which suggests that when it comes to that environment, work routine helps to reduce the burden. Such a result is understandable if we take into account that the test was carried out on a body which comprises uniformed services, wherein as a rule working according to a pre-determined procedure is conducive to a better performance of given tasks and affords greater safety to employees. In the Polish version of COPSOQ II, the scales associated with workplace pathologies were clearly defined. Instead a single "Offensive behaviors" factor, there are two in the Polish version: "Physical violence" which comprises scales associated with danger or infringement of physical inviolability and "Psychological violence" - associated with bullying and other forms of personal dignity infringements short of physical violence. Such a division seems to be a better match for the cultural relations in Poland. The impact of the cultural context is also visible when it comes to scales associated with interpersonal relations and organizational culture. The "Organizational relations" factors identified in the Polish version and "Relations within a team" reflect a clear distinction between psychosocial conditions shaped by superiors and colleagues. That difference between the Polish and the Dutch COPSOQ II versions remains cohesive with comparative tests between the national cultures of 
the two countries. As shown by Hofstede [13], the level of cultural hierarchy and acceptance associated with the hierarchy of social inequalities is three times stronger than in Denmark. In the Polish version, the scales which originally comprised the "Work organization and job contents" factor were included in the "Job commitment and development perspectives". This factor also included "Job satisfaction", which was an element of the "Work-individual relation" factor in the original version. However, subject literature [8] shows that there are significant links between job satisfaction and the meaning of work and job resources [24] as perceived by the individual, that is why the obtained structure of the factor in question remains theoretically valid. Whereas face validity dictates the performed factor name change.

The "Work-individual relation" did not figure in the Polish version at all. In the Polish version all the scales of that factor, with the exception of "Job satisfaction" were part of the "Health and wellbeing" factor. The "Job insecurity" scale is made up of questions which essentially apply to distress associated with lack of job security. All four questions in that scale begin with the phrase "Are you worried about ...?".That is why including that scale in the "Health and well-being" factor remains fully justifiable. The remaining two scales, i.e. "Familywork conflict" and "Work-family conflict" may be treated as a social health disorders operationalization [14].

\section{Analysis of correlations with other measures}

Criterion validity was tested using convergence analysis of measurements with other tools used to measure job demands and resources as well health consequences such as mental health disorders or burnout symptoms, the validity of which has already been verified. The correlation coefficients published in the paper were not adjusted by scales' reliability factors of COPSOQ II PL or other tools used as a criterion of validity. Thus, the real correlation coefficient values are undoubtedly higher that those shown in table 5 [4]. The strength of the relations was assessed in accordance with the classification proposed by Guilford [12].

\section{Physical violence}

Convergent validity indexes for all scales which operationalize physical violence at the workplace remain in accordance with theoretical assumptions. The correlations are statistically significant, and they are positive, which reflects the initial hypotheses. The power of disclosed relations agree with the results obtained by other researchers engaged with the consequences of experiencing physical violence at the workplace amongst uniformed services [10]. After years of studies on the interpersonal aspects of bullying, referring to the personalities of victims and perpetrators, after including organizational factors into the research, it turned out, that in correctly managed organizations bullying was scarce, even if individuals whose traits are conducive to bullying are employed therein [9]

\section{Organizational relations}

Also, all COPSOQ II PL scales which measure "Organizational relations" turned out to be valid pursuant to the adopted criteria. The performed correlation analyses yielded statistically significant results, the direction of the identified relations remains as expected and most relations are strong or very strong. Scales being a part of the "Organizational relations" factor were least correlated with the general state of health measured by GHQ $30[11,19]$, which is most probably associated with the nature of the validation group. Prison service officers are selected on the basis of their psychological suitability for the job, and as such they are a priori well suited for the working conditions and exhibit above average psychophysical resilience.

\section{Health and well-being}

All the scales part of the COPSOQ II PL used to measure health and well-being turned out to be valid. The obtained values of the assumed convergent validity indicators, even though below values which could have been expected, remain satisfactory.

\section{Demands at work}

All the assumed correlations pertaining to demands turned out to be statistically significant, whereas the lion's share was at least above-average. The convergent validity of the "Demands for hiding emotions" scale which is weakly or to a slight degree correlated with the adopted validity measures may raise some doubts, albeit its correlation with all measures is statistically significant. Here, the weak or slight relation with the health disorder measures adopted as validity indicators is surprising. Only the specification of the tested sample could have had an impact on the strength of the relation. Earlier tests point to links between hiding emotions and negative health consequences pertained to individuals which frequently come into contact with others as part of their 
professional duties [16], nevertheless in most cases these are representatives of professions where a psychological pre-selection is not carried out. Upon starting their job, the subjects part of the validity sample, are subjected to a psychological assessment in terms of emotional control, which might have a significant impact on expressing negative psychological health symptoms. That is why, weak correlations, but ones which are statistically significant and in accordance with expectations as to their direction, may be considered to be satisfactory in this case. At the same time, this might indicate the need for additional "Demands for hiding emotions" scale validity tests, for example by testing convergent validity with the CECS questionnaire [15] and by performing a correlation analysis with health well-being measures in other professional groups.

\section{Psychological violence}

The scales part of the COPSOQ II PL for measuring "Psychological violence" indicate a convergence of results with tools measuring organizational risks for bullying and possible health consequences associated with experiencing psychological bullying at the workplace. The obtained correlation results are not only statistically significant and in accordance with the expected direction, but also at least average in terms of strength, which should be taken to be satisfactory in light of the higher psychological resilience of the tested group.

\section{Work commitment and development perspectives}

Each COPSOQ II PL scale which was part of the "Commitment and development perspectives" also turned out to be valid. All the correlation coefficients are statistically significant, and their direction reflects theoretical expectations. The strength of those relations varies depending on the scale and criterion, however the results may be considered to be satisfactory.

\section{Relations within a team}

The theoretical assumption pertaining to the convergence of measurements obtained using "Social support from colleagues", "Social community at work" and "Mutual trust between employees" and the results obtained GHQ $30[11,19]$, OLBI [1], ORM [29] and PWP [5] turned out to be correct. And in this case, all correlations were also statistically significant, in accordance with the expected direction, and their strength may be considered to be satisfactory.

\section{CONCLUSIONS}

In accordance with the expectations of its authors, the Copenhagen Psychosocial Questionnaire is to be used to measure the psychosocial work environment, amongst others in order to assess occupational risk [23]. Following validation in a homogeneous work environment, which is recommended also by other researchers [3], the COPSOQ II PL satisfies the reliability and validity criteria, and also objectiveness and standardization criteria. From the point of view of criteria which a good psychometric tool for measuring psychosocial work hazards should satisfy, the COPSOQ II PL may be considered to be sufficient. It should also be noted that the standards for tools of this type should be developed for given professions or work environments. It is also worth pointing out that the prison service is a specific and thus far the only professional environment where the Polish COPSOQ II version was applied. Therefore, further tests on other work environments are recommended which would facilitate the development of standards and provide another verification of its psychometric properties.

\section{AUTHORS' DECLARATION:}

Study Design: Katarzyna Orlak, Dominik Gołuch, Mikołaj Stolarski; Data Collection: Katarzyna Orlak, Dominik Gołuch, Mikołaj Stolarski; Statistical Analysis: Katarzyna Orlak, Dominik Gołuch; Manuscript Preparation: Katarzyna Orlak, Dominik Gołuch, Mikołaj Stolarski. The Authors declare that there is no conflict of interests. 


\section{REFERENCES}

1. Baka Ł, Basińska BA. Psychometryczne właściwości polskiej wersji Oldenburskiego kwestionariusza wypalenia zawodowego (OLBI). Med Pr. 2016; 67:29-41.

2. Bakker AB, Demerouti E, Sanz-Vergel AI. Burnout and Work Engagement: The JD-R Approach. Annu Rev Organ Psychol Organ Behav. 2014; 1:389-411.

3. Berthelsen H, Hakanen J, Kristensen T, Lönnblad A, Westerlund H. A Qualitative Study on the Content Validity of the Social Capital Scales in the Copenhagen Psychosocial Questionnaire (COPSOQ II). Scand J Work Organ Psychol. 2016; 1:5.

4. Brzeziński J. Metodologia Badań Psychologicznych. Warszawa: Wydawnictwo Naukowe PWN; 2004.

5. Cieślak R, Widerszal-Bazyl M. Psychospołeczne Warunki Pracy. Podręcznik Do Kwestionariusza. Warszawa: ClOP-PIB; 2000.

6. Crawford ER, Lepine JA, Rich BL. Linking job demands and resources to employee engagement and burnout: a theoretical extension and meta-analytic test. J Appl Psychol. 2010; 95:834-848.

7. Dang C, Denis C, Gahide S, Chariot P, Lefèvre T. Violence at work: forensic medical examination of police officers assaulted while on duty: comparisons with other groups of workers in two centres of the Paris area, 2010-2012. Int Arch Occup Environ Health. 2016; 89:755-765.

8. Duffy RD, Autin KL, Bott EM. Work Volition and Job Satisfaction: Examining the Role of Work Meaning and Person-Environment Fit. Career Dev Q. 2015; 63:126-140.

9. Einarsen S, Hoel H, Zapf D, Cooper C. Bullying and Harassment in the Workplace: Developments in Theory, Research, and Practice. Crc Press; 2010.

10. Fitzgerald LF, Drasgow F, Hulin CL, Gelfand MJ, Magley VJ. Antecedents and consequences of sexual harassment in organizations: a test of an integrated model. J Appl Psychol. 1997; 82:578-589.

11. Frydecka D, Małyszczak K, Chachaj A, Kiejna A. Factorial structure of the general health questionnaire (GHQ-30). Psychiatr Pol. 2010; 44:341-359.

12. Guilford J. Podstawowe Metody Statystyczne w Psychologii i Pedagogice. Wyd. 2. Warszawa: Wydawnictwo Naukowe PWN; 1964.

13. Hofstede G, Hofstede GJ, Minkov M. Cultures and Organizations: Software of the Mind, Third Edition. 3 edition. New York: McGraw-Hill Education; 2010.

14. Huber M, Knottnerus JA, Green L, Horst H van der, Jadad AR, Kromhout D, Leonard B, Lorig K, Loureiro MI, Meer JWM van der, Schnabel P, Smith R, Weel C van, Smid H. How should we define health? BMJ. 2011;343. Available at: https://www.bmj. com/content/343/bmj.d4163 [Accessed February 8, 2020].

15. Juczyński Z. Narzędzia Pomiaru w Promocji i Psychologii Zdrowia. Warszawa: Pracownia Testów Psychologicznych Polskiego Towarzystwa Psychologicznego; 2009.

16. Lee B. Relationship Between Hiding Emotions and Health Outcomes Among South Korean Interactive Service Workers. Workplace Health Saf. 2016; 64:187-194.

17. Lee Joseph Cronbach, Meehl PE. Trafność i rzetelność testów psychologicznych. In: Brzeziński J, Hornowska E, Zakrzewsa M, eds. Trafność i Rzetelność Testów Psychologicznych Wybór Tekstów. Gdańsk: Gdańskie Wydawnictwo Psychologiczne; 2005:404-430.

18. Leka S, Jain A, Organization WH. Health Impact of Psychosocial Hazards at Work: An Overview. World Health Organization; 2010. Available at: http://apps.who.int/iris/bitstream/10665/44428/1/9789241500272_eng.pdf.

19. Małyszczak K, Pawlowski T. Discriminatory Parameters of Polish General Health Questionnaire (GHQ-30) for Different Scoring Methods. Adv Clin Exp Med. 2003; 12:621-624.

20. Moncada S, Utzet M, Molinero E, Llorens C, Moreno N, Galtés A, Navarro A. The copenhagen psychosocial questionnaire II (COPSOQ II) in Spain-A tool for psychosocial risk assessment at the workplace. Am J Ind Med. 2014; 57:97-107.

21. Nistor K, Ádám S, Cserháti Z, Szabó A, Zakor T, Stauder A. Psychometric characteristics of the Hungarian version of the Copenhagen Psychosocial Questionnaire II (COPSOQ II). Mentálhig És Pszichoszomatika. 2015; 16:179-207.

22. Orlak K, Tylka J. Temperament risk factor for mental health disturbances in the judiciary staff. Med Pr. 2017; 68:375-390.

23. Pejtersen JH, Kristensen TS, Borg V, Bjorner JB. The second version of the Copenhagen Psychosocial Questionnaire. Scand J Public Health. 2010; 38:8-24.

24. Potocka A, Waszkowska M. Application of job demands-resources model in research on relationships between job satisfaction, job resources, individual resources and job demands. Med Pr. 2013; 64:217-225.

25. Rosário S, Azevedo LF, Fonseca JA, Nienhaus A, Nübling M, da Costa JT. The Portuguese long version of the Copenhagen Psychosocial Questionnaire II (COPSOQ II) - a validation study. J Occup Med Toxicol. 2017; 12:24. 
26. Stansfeld SA, Shipley MJ, Head J, Fuhrer R. Repeated job strain and the risk of depression: Iongitudinal analyses from the Whitehall II study. Am J Public Health. 2012; 102:2360-2366.

27. Tahmassian K, Jalali Moghadam N. Relationship between self-efficacy and symptoms of anxiety, depression, worry and social avoidance in a normal sample of students. Iran J Psychiatry Behav Sci. 2011; 5:91-98.

28. Tavakol M, Dennick R. Making sense of Cronbach's alpha. Int J Med Educ. 2011; 2:53-55.

29. Warszewska-Makuch M. Warszewska-Makuch, M. (2010). Sprawozdanie z 3. Etapu Zadania Nr 4.S.36: Opracowanie Narzędzia Do Oceny Ryzyka Wystąpienia Mobbingu w Organizacji. Warszawa: Centralny Instytut Ochrony Pracy - Państwowy Instytut Badawczy; 2010.

30. WHO World Mental Health (WMH). Initiative Interview Translation Guidelines (Abridged version). 2003.

31. Widerszal-Bazyl M. [Copenhagen Psychosocial Questionnaire (COPSOQ) - Psychometric properties of selected scales in the Polish version. Med Pr. 2017; 68:329-348.

32. Zakrzewska M. Analiza Czynnikowa w Budowaniu i Sprawdzaniu Modeli Psychologicznych. Poznań: Wydawnictwo Naukowe UAM; 1994.

Cite this article as: Orlak K, Gołuch D, Stolarski M. Polish Adaptation Of The Copenhagen Psychosocial Questionnaire li (Copsoq li) In Polish Prison Service Staff - A Tool For Psychosocial Risk Assessment At The Workplace. Pol J Aviat Med Bioeng Psychol 2019; 25(1): 5-18. DOI: 10.13174/pjambp.07.12.2020.01 